Geochemistry and Geology of

Deep Drill Holes at Iron Canyon,

Lander County, Nevada

GE OLOG I C A L S URVEY B ULLETIN 1318 


\section{Geochemistry and Geology of Deep Drill Holes at Iron Canyon,}

Lander County, Nevada

By TED G. THEODORE and RALPH J. ROBERTS

With a section on

GEOPHYSICAL LOGS OF DRILL HOLE DDH-2

By CHARLES J. ZABLOCKI

G E O L O G I C A L S U R V E Y B U L L E T I N 1318

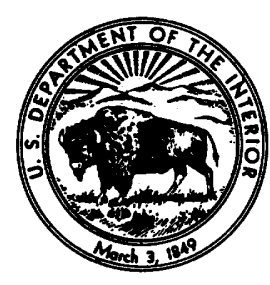


UNITED STATES DEPARTMENT OF THE INTERIOR

ROGERS G. B. MORTON, Secretary

\section{GEOLOGIGAL SURVEY}

W. A. Radlinski, Acting Director

Library of Congress Catalog Card No. 70-179677

For sale by the Superintendent of Documents, U.S. Government Printing Office Washington, D.C. 20402 - Price $1 \$$ (paper cover)

Stock Number 2401-1199 


\section{CONTENTS}

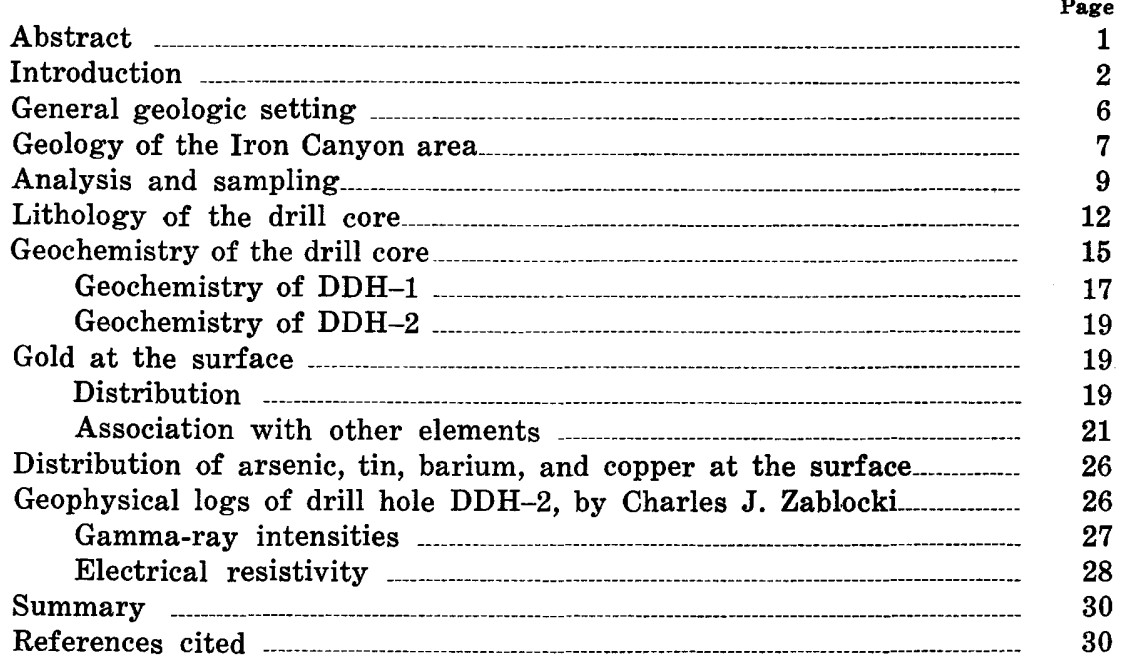

\section{ILLUSTRATIONS}

[Plates are in pocket]

Plate 1. Maps showing generalized geology and surface distribution of gold, arsenic, tin, barium, and copper.

2. Columnar sections showing lithology and geochemistry of DDH-1.

3. Columnar sections showing lithology and geochemistry of DDH-2.

4. Well log showing relative gamma-ray intensity and electrical resistivity in DDH-2 between depths of 1,814 and 3,965 feet.

FIgURE 1. Index map showing the location of the Copper Canyon area of the Battle Mountain mining district

2. Structural map of the area near Copper Canyon, Lander County, Nev

3. Whole-rock X-ray $\mathrm{CuKa}$ diffraction patterns from equal volumes of rock in DDH-1 in the interval 126-148 feet.

4. Graph showing range of geochemical background concentrations in 61 samples from DDH-1 and DDH-2. 
FIGURE 5. Diagram showing relative distribution of minerals adjacent to and in a fault breccia zone between 148 and 163 feet in $\mathrm{DDH}-1$

Page

6. Map showing distribution of gold in grab samples collected in underground workings along the Butte fault zone

7. Graph showing frequency distribution of gold in all surface samples collected in the Iron Canyon area.

8. Map showing elements that have significant positive Spearman correlation coefficients with gold at Iron Canyon....

\section{TABLES}

TABLE 1. Concentration of selected metals in drill core and in drill sludge (fine cuttings) from the same core interval.......

2. Typical partial analyses of water used during drilling

3. Qualitative results of spectrographic analyses of chassis grease applied to drill rods

4. Semiquantitative six-step spectrographic analyses of drilling mud components

5. Composite phase assemblages in country rock adjacent to a mineralized fault zone in DDH-1.

6. Drill core samples with anomalous concentrations of gold..- 


\title{
GEOCHEMISTRY AND GEOLOGY OF DEEP DRILL HOLES AT IRON CANYON, LANDER COUNTY, NEVADA
}

\author{
By Ted G. ThEODORE and RALPH J. ROBERTS
}

\begin{abstract}
The U.S. Geological Survey in 1967 undertook deep drilling projects in selected areas across north-central Nevada to determine the depth to the Roberts Mountains thrust fault and to obtain data on the underlying rocks. The Iron Canyon area, one of the areas selected for drilling, is 21/2 miles northeast of the deposits of base and precious metals centered at Copper Canyon, in the southeastern part of the Battle Mountain mining district.

Two holes were drilled at Iron Canyon to depths of 4,635 and 2,672 feet. They were collared in chert and argillite that contain black graphitic(?) shale partings. These rocks are part of the Lower or Middle Cambrian Scott Canyon Formation, which is a part of the siliceous assemblage in the upper plate of the Roberts Mountains thrust. Some interbedded limestone was penetrated, and the holes bottomed in less cherty and more hornfelsic rocks of the siliceous assemblage.

At the surface a broad pyrite halo surrounds the Copper Canyon deposits and geochemical data from one of the holes at Iron Canyon reveal the extent and nature of pyritic alteration at depth. In core from this drill hole, the distribution of barium and manganese best reflects the extent of the pyritic alteration.

The distribution of gold at depth and on the surface at Iron Canyon is strongly controlled by faults and fractures. The distribution of gold in the drill cores is spotty; gold is generally associated with base-metal sulfide veins along fractures. In the siliceous rock, the background concentration of gold is probably less than 0.02 parts per million. There are three thick intervals, all below 900 feet in the holes, across which gold is dispersed in amounts of about $0.09,0.10$, and 0.04 parts per million. Study of surface samples from within the pyrite halo at Iron Canyon revealed a strong positive association, at 99 percent confidence limits, between gold and copper, iron, bismuth, silver, mercury, and arsenic.

Continuous natural gamma-ray intensity and electrical resistivity measurements were made in the deeper hole between depths of 1,814 and 3,965 feet. Even though only about 3 percent total organic carbon (graphite?) was present, largely in continuous layers of black carbonaceous material along bedding planes, the organic carbon may have been responsible for the low ( $<1 \mathrm{ohm}$-meter) electrical resistivities that were measured.
\end{abstract}




\section{INTRODUCTION}

Studies by the U.S. Geological Survey during the last 30 years have clarified the major stratigraphic and structural controls of gold ore deposits in Nevada and have identified zones favorable for prospecting. One zone is the broad area covered by the upper plate of the Roberts Mountains thrust, principally in north-central Nevada (fig. 1). This plate, made up of volcanic rocks, chert, shale, and quartzite of early and middle Paleozoic age, moved eastward over lowerplate carbonate rocks of equivalent age (Roberts and others, 1958; Roberts, 1966). In places, the carbonate rocks and overlying plate were domed and cut by intrusive stocks along northwest-trending zones. Ore bodies formed in the domed areas in three principal settings: along fractures in the lower plate at the Carlin gold mine and at Cortez (Hardie, 1966; Elliott and Wells, 1968), along the thrust zone at Gold Acres (Wrucke and others, 1968), and locally in the upper plate in the Tenabo area, near Gold Acres (Wrucke and others, 1968).

Until 1967, exploration was confined largely to areas where the mineralized rocks in the lower plate or along the thrust zone were exposed at the surface. However, the occurrence of small ore bodies along faults in many areas covered by upper-plate rocks indicates that undiscovered ore may also exist at depth. Surface sampling and drilling might outline areas of potential interest to the mining industry. Accordingly, as part of the Heavy Metals program, the U.S. Geological Survey in 1967 undertook deep drilling projects in north-central Nevada to determine the depth to the Roberts Mountains thrust and to sample and analyze the underlying rocks. One of the areas drilled early in the program was in the Battle Mountain mining district, at Iron Canyon, about 21/2 miles northeast of the well-known Copper Canyon metal deposits (fig. 2).

Copper-gold ore bodies in the Battle Mountain district yielded 150,282 ounces of gold, $2,130,287$ ounces of silver, and $31,826,834$ pounds of copper up to 1961, mostly from the Copper Canyon underground workings. This impressive production was entirely from rocks above the Roberts Mountains thrust and constituted a significant anomaly. As this general area seemed to be favorable for geological and geochemical testing of both upper-and lower-plate rocks, a diamond-drilling project was set up.

Two holes were drilled in Iron Canyon (fig. 2). DDH-1 is within a group of three patented lode mining claims (identified as the Wedge, Compromise, and Globe claims) in the $\mathrm{W} 1 / 2$ sec. $23, \mathrm{~T} .31$ N., R. 43 E. These three claims and six others around the Iron Canyon mine are currently owned by Duval Corp. of Tucson, Ariz. 
DDH-2 is within the Star group of 20 unpatented lode mining claims and four placer claims in the E1/2 sec. 23, T. 31 N., R. 43 E. The mineral rights to the lode claims are owned by G. A. and G. C.

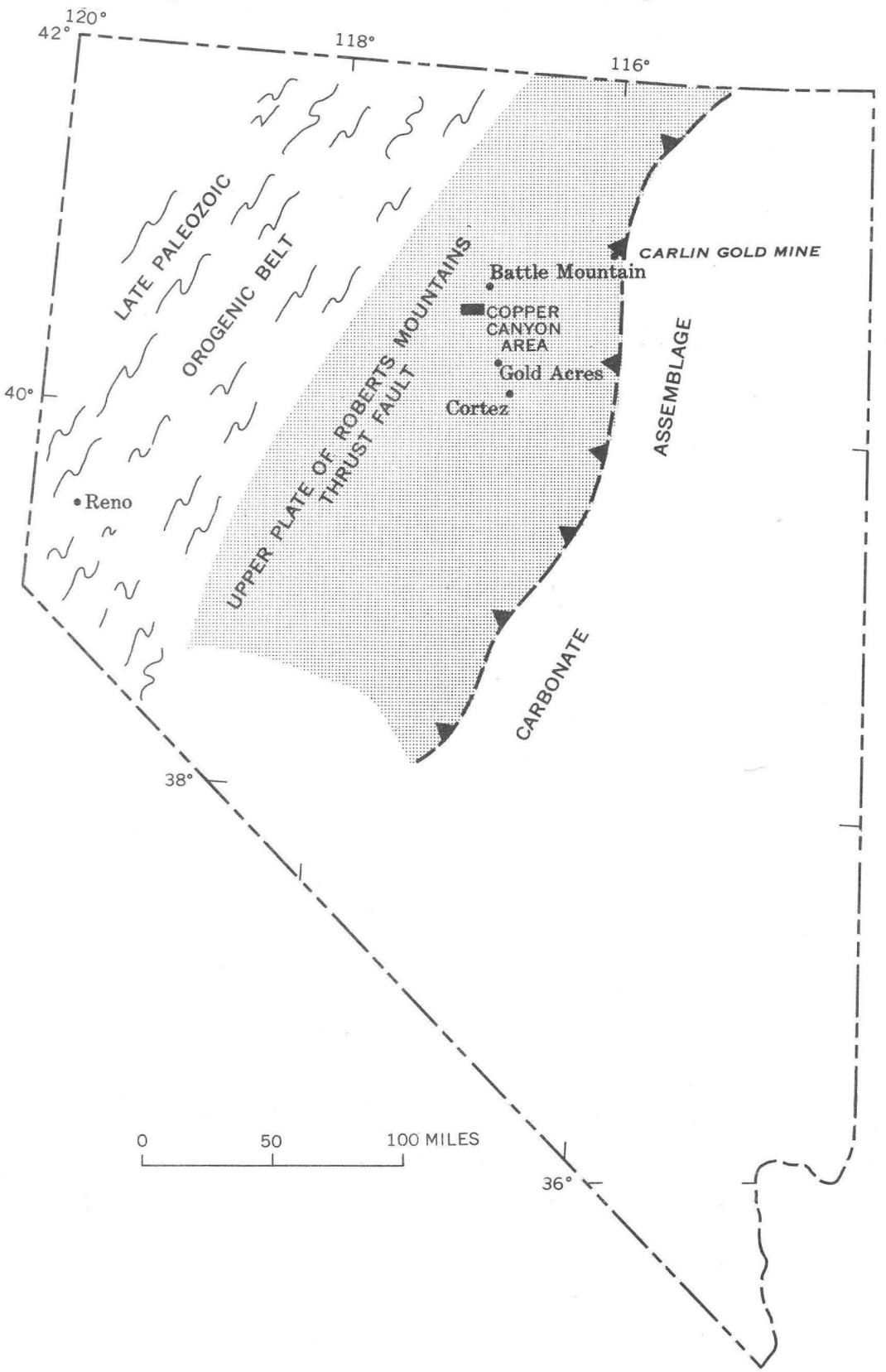

Figure 1.-Location of the Copper Canyon area of the Battle Mountain mining district. The distribution of Paleozoic rocks in the Roberts Mountains thrust plate after Mississippian thrusting is indicated by the stippled pattern. 


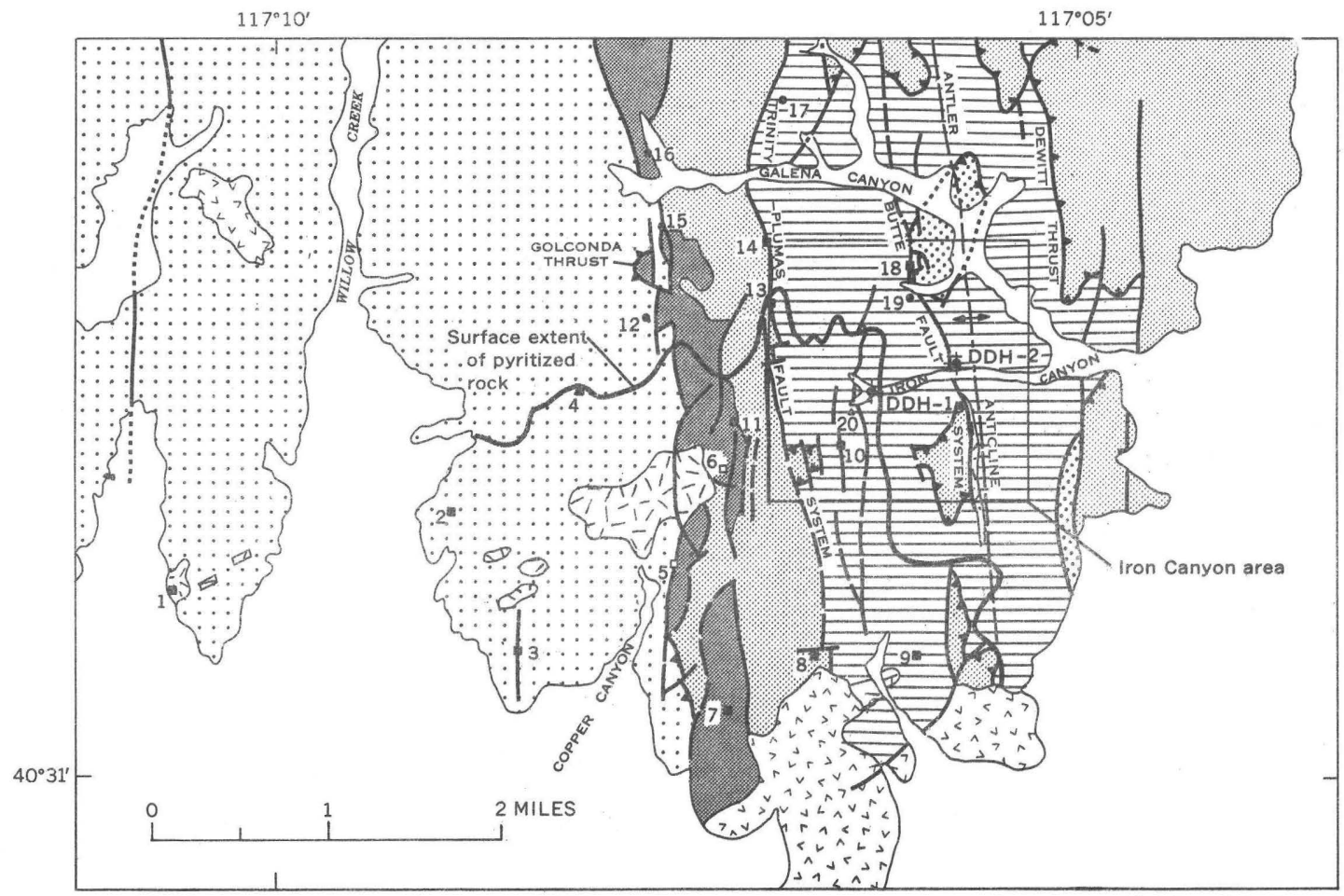

LIST OF MINES

1. Modoc

2. Eldorado

3. Wilson-Independence

4. Elko-Lander

5. Copper Canyon

6. Copper Canyon-Duval

7. 'Tomboy

8. Gold Cash

9. Nevada-Omaha

10. Buzzard

11. Independence

12. Nevada

13. Plumas

14. Humbug

15. Blossom

16. White and Shiloh

17. Trinity

18. Butte

19. Post

20. Iron Canyon

Geology modified from Roberts and 


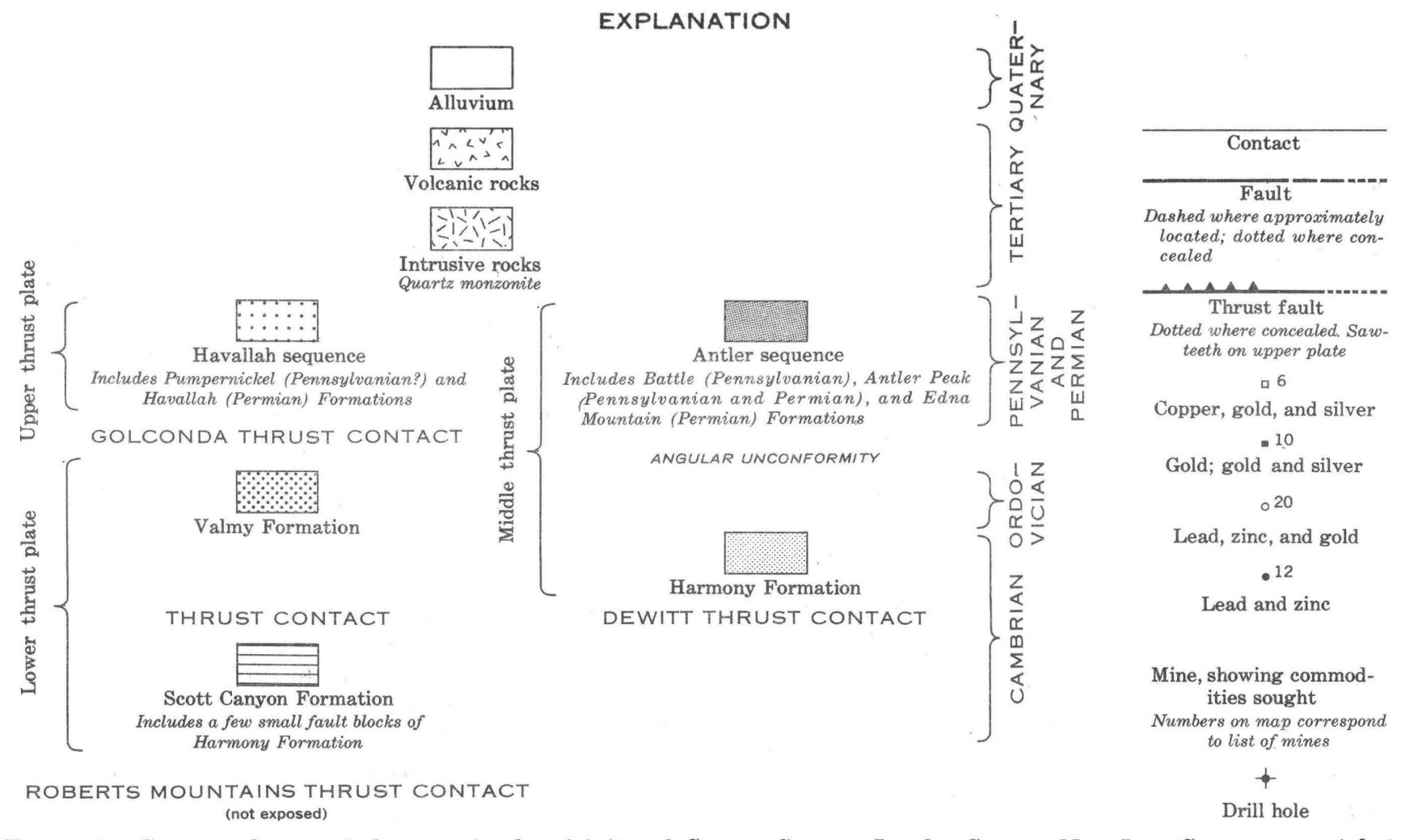

FIGURE 2.-Structural map of the area in the vicinity of Copper Canyon, Lander County, Nev. Iron Canyon area (pl. 1; fig. 8 ) is indicated by square. 
Hinman of Battle Mountain, Nev.; the placer claims are leased to the family of V. C. Frazier.

Several factors governed location of the drill sites. To penetrate the carbonate rocks of the lower plate of the Roberts Mountains thrust, the holes were drilled near the trace of the Antler anticline (fig. 2), a regionally defined structure (Roberts, 1964, pl. 6) whose inferred trace crosses Iron Canyon. Also, the holes were drilled outside of intensely altered or mineralized zones in order to facilitate drilling and to ensure maximum penetration with a minimum of caving.

This report summarizes geologic, geochemical, and geophysical information from the two holes drilled in this area, and briefly discusses the distribution of gold and the element association of gold in rocks at the surface around the drill sites.

Acknowledgments.-Drill core was boxed and split by W. M. Marlow, U.S. Geological Survey. Earlier drafts of the manuscript were reviewed by T. J. Armbrustmacher and A. A. R. Zohdy.

\section{GENERAL GEOLOGIC SETTING}

The Copper Canyon area has been overridden primarily by three successive thrust plates (Roberts, 1964): (1) the middle Paleozoic Roberts Mountains thrust, (2) the middle Paleozoic Dewitt thrust, and (3) the early Mesozoic Golconda thrust. The Roberts Mountains thrust does not crop out in the Antler Peak quadrangle but is present in the subsurface. This lowest thrust plate (the Roberts Mountains plate) is made up of chert, shale, argillite, and greenstone of the Lower or Middle Cambrian Scott Canyon Formation and quartzite of the Lower and Middle Ordovician Valmy Formation. These two formations are in fault contact near the Butte and Post mines (fig. 2) - along both steeply dipping Tertiary normal faults and a shallow-dipping Paleozoic thrust fault. Both drill holes at Iron Canyon started in this plate.

The base of the middle plate-the Dewitt thrust-does crop out in the quadrangle (fig. 2). Along this thrust, arkosic sandstones and shales of the Harmony Formation moved eastward across rocks of the Valmy and Scott Canyon Formations. Here in the middle plate, the Harmony Formation is overlain unconformably by the autochthonous Antler sequence (Roberts, 1964, p. A27) which consists of three formations: the Middle Pennsylvanian Battle Formation, the Upper Pennsylvanian and Lower Permian Antler Peak Limestone, and the Upper Permian Edna Mountain Formation. The Antler Peak Limestone and the Edna Mountain Formation make up only a small fraction of the total outcrop area of the Antler sequence near Copper Canyon. The Battle Formation covers 
the largest area and comprises a lower calcareous conglomerate, a middle shaly hornfels, and an upper chert pebble conglomerate. The lower calcareous conglomerate contains most of the ore bodies that have been mined at Copper Canyon. Ore was mined in underground workings in the past and currently is being mined in an open pit by Duval Corp. (Sayers and others, 1968). Ore also occurs along fractures in the underlying Harmony Formation.

The upper plate is made up of the Havallah sequence (Roberts, 1964, p. A37). This group of rocks is in fault contact with the middle plate along the early Mesozoic Golconda thrust, which crops out near the Nevada mine (fig. 2), and also along Tertiary normal faults. Two formations make up the Havallah sequence: the Pennsylvanian(?) Pumpernickel Formation near Copper Canyon and the Pennsylvanian and Permian Havallah Formation west of Willow Creek. In the Copper Canyon area, the rocks of the upper plate primarily consist of chert and argillite, but also contain lesser amounts of quartzite.

The Tertiary quartz monzonite stock at Copper Canyon, the largest intrusive exposure in the southern half of the quadrangle, is in the core area of a pyrite zone (fig. 2) (Theodore and Blake, 1969). In the upper structural block, the northern edge of the pyrite zone generally parallels the northern contact of the stock with the Pumpernickel Formation. Here, in the Golconda plate, pyrite has been introduced into the country rock up to about a mile north of the stock. To the northeast and southeast, however, the pyrite zone is much broader, probably because of extensive lateral migration of hydrothermal solutions, facilitated by the abundance of fractures here, and also perhaps because of the occurrence of small intrusives at shallow depths.

\section{GEOLOGY OF THE IRON CANYON AREA}

The Iron Canyon area (pl. 1) is underlain almost entirely by the lowest of the aforementioned three structural blocks. The oldest rocks are cherts, argillites, and greenstones (altered andesites and (or) basalts) of the Scott Canyon Formation. Although the rocks in this part of the Antler Peak quadrangle may be described as belonging to three structural blocks, there are many minor thrust faults within the lowest and uppermost blocks. Some of these minor thrusts have been recognized at Iron Canyon (pl. 1) in the lowest block, generally between Scott Canyon greenstones and undifferentiated cherts and argillites.

Some of the original thrust relationships between Scott Canyon and Harmony are still recognizable at Iron Canyon, even though many contacts between the Harmany and Scott Canyon are now 
along north-trending steeply dipping normal faults of Tertiary age. A thrust plate of quartzites of the Ordovician Valmy Formation crops out in the north-central part of the Iron Canyon area, near the Butte and Post mines. Normal faults however, are the dominant geologic features of the Iron Canyon area, both structurally and economically, because all known metal deposits are localized along these faults.

Almost the entire southwestern quarter of the Iron Canyon area (pl. 1) is within the pyrite zone that surrounds the Copper Canyon stock. The average amount of unoxidized pyrite in rocks at the surface within the zone is probably less than 1 percent. The occurrence of indigenous, fringing, and exotic (Blanchard, 1968) limonite throughout this part of the area, however, provides evidence of extensive pyritization.

Bleaching occurred concomitantly with the introduction of pyrite. At the eastern edge of the pyrite zone, the dominant grays of the unaltered Scott Canyon cherts and argillites give way to much lighter hues of gray, and moderate amounts of brown iron oxides and green iron arsenates occur along the weathered surfaces. This bleaching, generally more pronounced in argillite than in chert, was accompanied by only slight quartz recrystallization. About 700 feet in from the edge of the pyrite halo, ocher-brown iron oxide coatings are much more abundant on fractures, and many rocks have been bleached almost milk white. In addition, fractures in many outcrops are commonly coated with an earthy brick-red exotic iron oxide. Chert beds have been recrystallized, and vugs of open-cavity quartz fillings are ubiquitous.

Near the western edge of the Iron Canyon area, in the vicinity of the Trinity-Plumas fault system (fig. 2), fractures in sandstones and micaceous arkoses of the Harmony Formation, 700 feet within the pyrite zone, have moderate to heavy coatings of brown to reddish-brown iron oxide. Also, these rocks, which are olive green to green where unaltered, are irregularly bleached grayish white at a scale of several tens of feet. Shaly beds are not as intensely altered. Within the pyrite zone, a progression of different alteration effects is apparently associated with the Trinity-Plumas fault trace. At about 150 feet from the fault, the amount of exotic ocher iron oxides begins to increase (brown varieties are dominant); at about 30 feet from the fault zone, pyrite vugs are very common, and ocher iron oxides are dominant; and at the approximately 10-foot-thick fault zone itself, brick-red iron oxides are dominant. Although many different conditions can affect the color of limonite (Blanchard, 1968, p. 89-91), the limonites here associated with 
the fault trace are interpreted as (1) indigenous goethite, with transported goethite, (2) transported goethite, and (3) hematite transported along the fault zone itself-all derived principally from the oxidation of pyrite.

\section{ANALYSIS AND SAMPLING}

All the drill-core and surface samples collected during the study were analyzed either in the mobile field laboratories or in the permanent analytical laboratories of the U.S. Geological Survey. Gold was determined by using the wet chemical techniques of atomic absorption spectrophotometry (Huffman and others, 1967). Mercury was determined by an instrumental atomic absorption technique (Vaughn and McCarthy, 1964). The concentrations of 29 other elements were determined by emission spectrographic methods (Grimes and Marranzino, 1968). A few antimony analyses were made using wet chemical techniques (Ward and others, 1963), and a few samples were sent to commercial laboratories for gold and silver fire-assay.

Cores were recovered from almost 98 percent of the lengths of the two holes. The only notable loss occurred in broken and shattered rock adjacent to some faults. The core was broken in the field to a size suitable for crushing in the Survey laboratories. A 6-inch core sample from every 5-foot intercept was left intact in the event that additional petrographic studies were undertaken. Systematic 5-foot channel samples, consisting of about one-third of the $21 / 8-13 / 8$-inch diameter core over a 5 -foot intercept, were obtained to a depth of 1,600 feet in each hole. From 1,600 feet to the bottom of each hole, samples were composited from chips collected about every 2 to 3 inches along every 10 feet of core. In addition to these systematic samples, samples were collected of all veins and from unmineralized 1-2-foot intercepts to establish the geochemical background in the holes.

The surface samples consisted of approximately 2 pounds of rock chips collected over an approximately 10 foot-square outcrop face. Also, at many outcrops, samples of mineralized rock, barren host rock, and iron oxide veins were collected.

Although surface and core samples were both analyzed for 31 different elements, the drill-core distributions of only lead, copper, molybdenum, vanadium, cobalt, chromium, nickel, zinc, boron, arsenic, manganese, and barium are presented in this report, together with anomalous drill-core concentrations of gold. From the surface samples, only the distributions of gold, arsenic, barium, tin, and copper are presented. 
Possible sources of core contamination.-A comparison of drillsludge analyses with drill-core analyses from the same interval (table 1) suggested that we should check the possibility that cores

TABLE 1.-Concentration, in parts per million, of selected metals in drill core and in drill sludge (fine cuttings) from the same interval

$[N$, not detected; $L$, detected in amounts less than indicated. Analysts : R. T. Hopkins, Jr., K. J. Curry]

\begin{tabular}{|c|c|c|c|c|c|c|c|c|c|c|}
\hline \multirow{2}{*}{$\begin{array}{l}\text { Core intercept } \\
\text { sampled from } \\
\text { DDH-2 (ft) }\end{array}$} & \multicolumn{2}{|c|}{ Tungsten } & \multicolumn{2}{|c|}{ Zinc } & \multicolumn{2}{|c|}{ Copper } & \multicolumn{2}{|c|}{ Nickel } & \multicolumn{2}{|c|}{ Lead } \\
\hline & Core & Sludge & Core & Sludge & Core & Sludge & Core & Sludge & Core & Sludge \\
\hline $\begin{array}{l}3,059-68 \ldots \ldots \\
3,138-44 \ldots \\
3,144-53, \ldots \\
3,153-65 \ldots \\
3,165-75 \ldots \ldots\end{array}$ & $\mathrm{L}(\mathbf{5 0}) \underset{\mathrm{N}}{\stackrel{N}{N}}$ & $\begin{array}{r}50 \\
50 \\
100 \\
\mathbf{L}(50) \\
50\end{array}$ & $\begin{array}{r}200 \\
1,500 \\
\mathrm{~N} \\
\mathrm{~N} \\
\mathrm{~N}\end{array}$ & $\begin{array}{r}500 \\
200 \\
\mathrm{~N} \\
\mathrm{~N} \\
\mathrm{~L}(200)\end{array}$ & $\begin{array}{l}150 \\
300 \\
150 \\
150 \\
150\end{array}$ & $\begin{array}{r}100 \\
200 \\
50 \\
30 \\
100\end{array}$ & $\begin{array}{r}50 \\
100 \\
50 \\
30 \\
70\end{array}$ & $\begin{array}{l}70 \\
50 \\
30 \\
20 \\
70\end{array}$ & $\begin{array}{r}200 \\
5,000 \\
15 \\
\mathrm{~L}(10) \\
150\end{array}$ & $\begin{array}{l}500 \\
500 \\
200 \\
100 \\
300\end{array}$ \\
\hline
\end{tabular}

might have been contaminated because of the drilling techniques used. The most obvious source of contamination is the water used to cool the bits and to remove sludge from the hole. Partial analyses of water samples collected at their source and from the water storage tanks at the drill sites are given in table 2. Samples were

TABLE 2.-Typical partial analyses, in milligrams per liter, of water used during drilling

[Cu and $\mathrm{Pb}$ tested for but not found. C. E. Roberson, analyst]

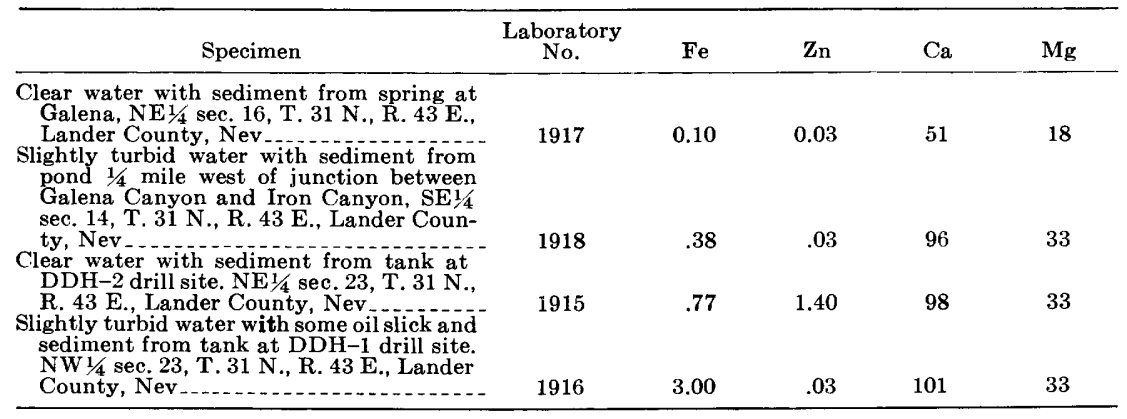

taken from the storage tanks before the water entered the closed circulation system used to cool the drill bits. These analyses suggest that the water did not contain significant amounts of copper, lead, or zinc. During drilling, a scum of grease from the drill rods accumulates on the primary return tank of the water circulation system. The grease contains many elements (table 3); a 9-gram sample (specimen 3 , table 3 ), may yield a sum containing about $1,800 \mathrm{ppm}$ (parts per million) lead, $120 \mathrm{ppm}$ copper, and $70 \mathrm{ppm}$ zinc (B. H. Madison, written commun., 1967). Because water is recirculated from this tank with the grease scum, some elements in base-metal veins may have been slightly dispersed over core intercepts longer than those they originally occupied. 
TABLE 3.-Qualitative results of spectrographic analyses of chassis grease applied to drill rods

[Dash leaders (....), not found ; B. H. Madison, analyst]

\begin{tabular}{|c|c|c|c|c|c|c|}
\hline Specimen & $\begin{array}{c}\text { Laboratory } \\
\text { No. }\end{array}$ & $\begin{array}{c}\text { Sample } \\
\text { weight } \\
\text { (grams) }\end{array}$ & $\begin{array}{l}\text { Weight } \\
\text { ash } \\
\text { (grams) }\end{array}$ & $\begin{array}{l}\text { Major } \\
\text { elements }\end{array}$ & $\begin{array}{l}\text { Minor } \\
\text { elements }\end{array}$ & $\begin{array}{c}\text { Trace } \\
\text { elements }\end{array}$ \\
\hline $\begin{array}{l}\text { 1. Fresh grease that probably } \\
\text { contains a mixed thickener } \\
\text { of calcium and aluminum } \\
\text { stearates with magnesium } \\
\text { salts and silicon as fillers. }\end{array}$ & $\mathrm{ACO}-444 \mathrm{a}$ & 9.45 & 0.87 & $\begin{array}{l}\mathrm{Ca} \\
\mathrm{Mg}\end{array}$ & $\mathrm{Si}$ & - \\
\hline 2. Do Don & $\mathrm{ACO}-444 \mathrm{~b}$ & 10.89 & .97 & $\begin{array}{l}\mathrm{Ca} \\
\mathrm{Mg}\end{array}$ & $\mathrm{Si}$ & $\ldots$ \\
\hline $\begin{array}{l}\text { 3. Used grease from drill rods } \\
\text { after extended drilling } \\
\text { operations. }\end{array}$ & $\mathrm{ACO}-445$ & 8.81 & 2.10 & $\begin{array}{l}\mathrm{Ca} \\
\mathrm{Al} \\
\mathrm{Mg} \\
\mathrm{Fe} \\
\mathrm{Si} \\
\mathrm{Pb} \\
\mathrm{Cu}\end{array}$ & $\begin{array}{l}T_{1} \\
\mathbf{V} \\
\text { Cd } \\
\mathbf{Z}_{\mathrm{n}}\end{array}$ & $\begin{array}{l}\mathrm{Z}_{\mathbf{T}} \\
\mathrm{Na} \\
\mathrm{B} \\
\mathrm{Mn} \\
\mathrm{Be}\end{array}$ \\
\hline
\end{tabular}

Other possible sources of contamination include light oil used in drilling the uppermost several hundred feet of DDH-2, cement used in the holes to stop circulation losses, the drill bits and drill rods, and a drilling mud used to drill DDH-2 below 4,300 feet. Spectrochemical analysis of the oil revealed the presence of lead (A. P. Marranzino, written commun., 1967). The bits are composed of tungsten carbide containing several bonding metals that have low melting points: copper, aluminum, manganese, nickel, and cobalt (W. E. Emerick, oral commun., 1968). The anomalous concentration of tungsten in some of the cuttings (table 1) is probably due to contamination from drill-bit metal. Analyses of

TABLE 4.-Semiquantitative six-step spectrographic analyses, in weight percent, of drilling mud components

[M, major constituent ( $>10$ percent); dashed leaders (...), not found. $H$. Bastron, analyst. Results for all but rock salt expressed in percent of the ash. Looked for but not found: $\mathrm{As}, \mathrm{Au}, \mathrm{Be}, \mathrm{Bi}, \mathrm{Ce}, \mathrm{Cd}, \mathrm{Ga}, \mathrm{Ge}, \mathrm{Hf}, \mathrm{Hg}, \mathrm{In}, \mathrm{La}, \mathrm{Li}, \mathrm{Nb}, \mathrm{Pd}, \mathrm{Pt}, \mathrm{Re}, \mathrm{Sb}, \mathrm{Sc}, \mathrm{Sn}, \mathrm{Ta}, \mathrm{Te}, \mathrm{Th}$, Tl, U, W, Y, Yb, Zn, Eu]

\begin{tabular}{|c|c|c|c|c|c|}
\hline Drilling mud.... & "Wolf" & Rock salt & $\begin{array}{l}\text { Walnut } \\
\text { powder }\end{array}$ & "Q-Brokin" & "Lo-Loss" \\
\hline Ash percent.. & 30 & $\ldots \ldots \ldots$ & 1.3 & 23 & 5.4 \\
\hline Laboratory No & M105029 & M105030 & M106031 & M105032 & M106033 \\
\hline 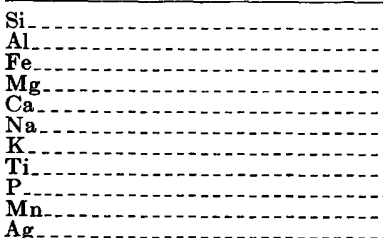 & $\begin{array}{l}1.0 \\
.2 \\
.1 \\
.07 \\
1.0 \\
.002 \\
.0015\end{array}$ & $\begin{array}{c}0.02 \\
3^{3} \\
\mathbf{M}^{2}\end{array}$ & $\begin{array}{l}3.0 \\
1.5 \\
1.5 \\
1.0 \\
\mathrm{M} \\
7.0 \\
\mathrm{M} \\
.1 \\
.7 \\
.05\end{array}$ & $\begin{array}{l}0.15 \\
.2 \\
. \mathrm{M} \\
.5 \\
3.0 \\
7.0 \\
1.5 \\
.007 \\
.1005\end{array}$ & $\begin{array}{l}1.5 \\
.01 \\
.1 \\
.7 \\
2.0 \\
. \mathrm{M} \\
7.0 \\
.002 \\
5.0 \\
.003\end{array}$ \\
\hline 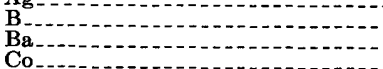 & .05 & - & $\begin{array}{l}.03 \\
.05 \\
0015\end{array}$ & .0015 & .003 \\
\hline 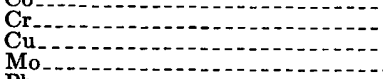 & $\begin{array}{l}.002 \\
.002 \\
\end{array}$ & $.003^{-1}$ & $\begin{array}{l}.0015 \\
.01 \\
.1 \\
.-2 .-1\end{array}$ & $\mathrm{M}^{1}$ & $\begin{array}{l}.003 \\
.01 \\
.015\end{array}$ \\
\hline $\begin{array}{l}\mathrm{Pb} \\
\mathrm{Sr} \\
\mathrm{V} \\
\mathrm{V}\end{array}$ & .01 & .003 & $\begin{array}{l}.02 \\
.1 \\
.002 \\
.005\end{array}$ & $\begin{array}{l}.015 \\
.005 \\
.005\end{array}$ & .05 \\
\hline
\end{tabular}


the five components mixed with water to make the drilling mud indicate that, of the heavier elements, the most likely contaminants are chromium and iron (table 4).

\section{LITHOLOGY OF THE DRILL CORE}

The rocks penetrated by the two holes are generally very similar. Each hole was collared in chert or argillite that has black graphitic(?) shale partings (the Scott Canyon Formation), downward they penetrated a heterogeneous mixture of siliceous rocks, and bottomed in a slightly less cherty, more hornfelsic siliceous facies (pls. 2 and 3). Some interbedded limestone was penetrated, also numerous faults and fault breccias. Several dikes, most of which are felsic granites or quartz monzonites, were also penetrated. Some of the dikes are altered. The extent of alteration in the drill core is indicated by circles along the lithologic strip logs (pls. 2 and 3 ).

Lithologies are extremely varied over very short intervals. Typically, chert, argillite, shale, quartzite, and siltstone are all interbedded on a scale of inches at all depths. The lithologic logs are thus generalizations showing the most common lithology over given intercepts. In addition, bedding is extremely disrupted and contorted, probably during both diagenesis and later folding. For example, in a zone of extremely deformed argillite and quartzite between 1,539 and 1,648 feet in DDH-1 (pl. 2), quartzite phacoids "swim" in a finer, apparently more ductile argillite matrix. Ptygmatic folds are very common here, and the hole penetrated the hinge region of several isoclinal folds with approximately horizontal axial planes. Owing to these structural complexities and the absence of any distinct lithologic markers both at the surface and at depth, a precise stratigraphy could not be established for the Scott Canyon Formation. Core from both holes contains various sulfide minerals, both disseminated and in veins; the more important sulfide concentrations are noted on plates 2 and 3.

The electrical conductivity of black carbonaceous shales in the Scott Canyon Formation is very high and will be discussed in the section "Electrical Resistivity." Several core samples of black shale were studied by whole-rock X-ray diffraction techniques and under the microscope. The rocks consist primarily of quartz and illite; small amounts or orthoclase, pyrite, and montmorillonite (trace amounts) were detected in all black shale samples, and minor amounts of kaolinite occur in some samples. Microscopic study revealed that the shales are dark gray to black largely because of thin 
films of carbonaceous material or carbon concentrated along bedding planes. The average total carbon content of three grab samples is 3.22 weight percent (range: 2.68 to 3.70 ); more than 85 percent of the carbon is organic rather than carbonate carbon (Irving May, written commun., 1969). Even if all the organic carbon were graphite, the total graphite content of these rocks would still be too low to detect on an X-ray diffractogram of a whole-rock sample. We were not able to determine the actual crystal form of the carbon; however, study of carbon concentrated by flotation techniques suggested that much of it may be amorphous.

$\mathrm{DDH}-1$ is within the pyritic alteration halo (pl. 1). This hole penetrated two prominent zones of pyritized rock: from about 60 to 350 feet and from 750 to 1,100 feet (pl. 2). Both zones are symmetrically disposed about two fault zones, at depths of 160 and 950 feet. The geometry of the pyrite envelope at depth and at the surface requires that its outer edge dip, perhaps quite irregularly, westward - that is, toward the Copper Canyon stock.

Near the surface, DDH-1 provided continuous core from unbleached gray carbonaceous chert (126 ft. deep) through intensely bleached and brecciated rocks centered at a 15-foot-wide mineralized fault zone between 148 and 163 feet. Several closely spaced samples were collected between depths of 126 and 154 feet and were studied by X-ray and under the microscope. The mineralogy of these rocks is summarized in table 5. Quartz was extensively remobilized in the

TABLE 5.-Composite phase assemblages in country rock adjacent to a mineralized fault zone in $D D H-1$

Samples (depths in $\mathrm{ft}$ )

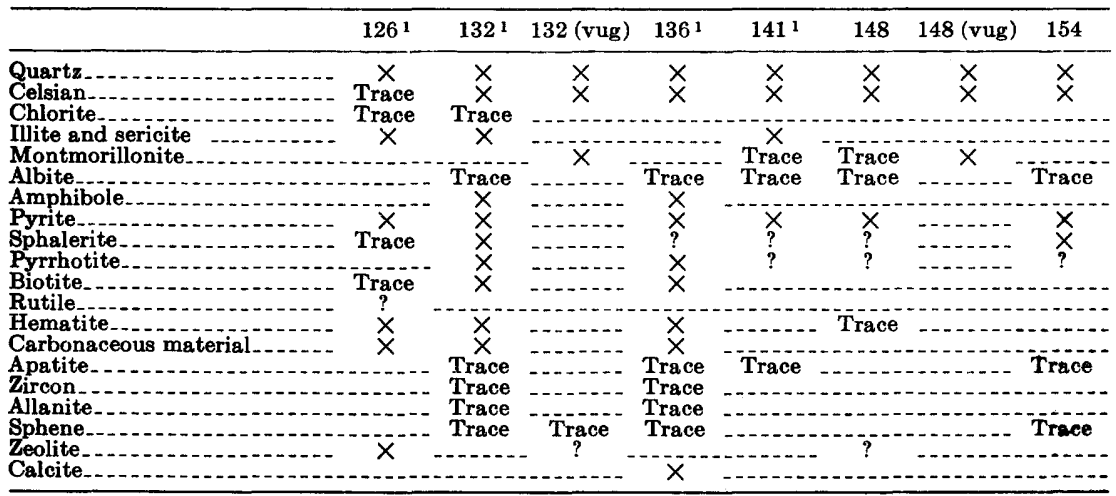

1 Thin section prepared.

unbleached chert (126 ft), as indicated by numerous quartz veins as much as $4 \mathrm{~mm}$ thick. White mica (illite and (or) sericite) is commonly associated spatially with the quartz veins. Pyrite cubes, less 
than $1 \mathrm{~mm}$ across and partly altered to hematite, are sprinkled through the chert. Biotite, only in trace amounts, has been partly

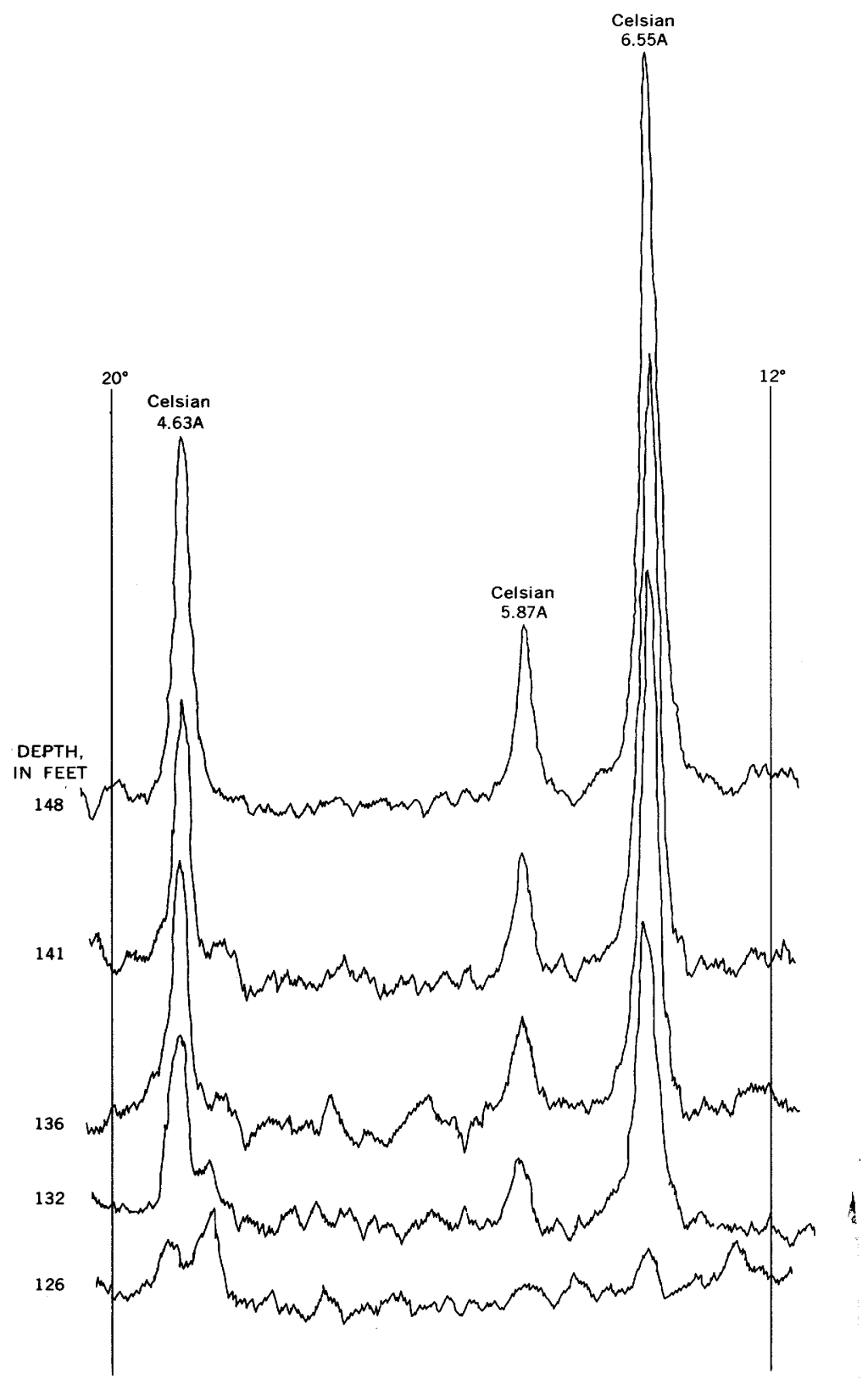

FIGURE 3.-Whole-rock X-ray CuKa diffraction patterns from equal volumes of rock in DDH-1, in the interval 126-148 feet. Degree of alteration and bleaching increases with depth. 
replaced by chlorite. The rock also contains small amounts of sphalerite, celsian (barium feldspar, $\mathrm{BaAl}_{2} \mathrm{Si}_{2} 0_{8}$ ), and a zeolite.

Bleached rocks were penetrated at 130 feet. Down through the bleached area to 148 feet, where the fault breccia begins, celsian becomes increasingly abundant (fig. 3). A colorless amphibole (tremolite?) occurs in some rocks and is commonly intergrown with pyrrhotite. There is probably more than one generation of pyrite: an early pyrite disseminated in the rocks and a later pyrite in solution cavities. Traces of sphalerite occur across the bleached area outside the fault zone, and sphalerite is the most abundant sulfide along one of the fault strands (at $154 \mathrm{ft}$ ). Clay minerals are not very common in these rocks, although montmorillonite does constitute the major phase in some vugs near the upper part of the fault zone.

\section{GEOCHEMISTRY OF THE DRILL CORE}

We established a geochemical background for siliceous rocks from the Scott Canyon Formation from the analyses of 61 short segments of drill core. Most samples are not bleached or altered; however, a few contain traces of disseminated sulfides and are partially bleached. In these 61 background samples, there is no detectable bismuth, cadmium, antimony, tin, or tungsten. Many elements have a broad range of concentration in the background samples; for example, barium has $15-5,000 \mathrm{ppm}$, vanadium, $15-7,000 \mathrm{ppm}$ (fig. 4). The highest barium values in these samples of barren host rock are from the upper part of DDH-1 (pl. 2), a zone of bleached, altered rocks and therefore probably not truly representative of unmineralized rock. Also, many of the background samples are rock with abundant black graphitic(?) shale partings that have high concentrations of vanadium and molybdenum. The arithmetic mean of vanadium from all 61 samples is $492 \mathrm{ppm}$, and the mean of molybdenum in 33 samples is $28 \mathrm{ppm}$. Geochemical background for arsenic and zinc in siliceous rocks of the Scott Canyon Formation has not been determined because of the high detection limits for these elements by spectrographic techniques. The arithmetic mean of 24 wet chemical antimony analyses of drill core is $5 \mathrm{ppm}$.

Background concentrations of silver and gold were too low to plot at the same scale as the other elements (fig. 4) (the mean of 19 gold determinations was $0.03 \mathrm{ppm}$ ). Gold background in the Scott Canyon Formation is generally below the detection limit; gold was not detected in approximately 700 of 1,100 samples from the two holes. There are, however, three intervals of drill core in which gold is dispersed at values above background (table 6) : 885-2,120 feet in DDH-1 and 3,045-3,144 and 4,310-4,565 feet in DDH-2. 


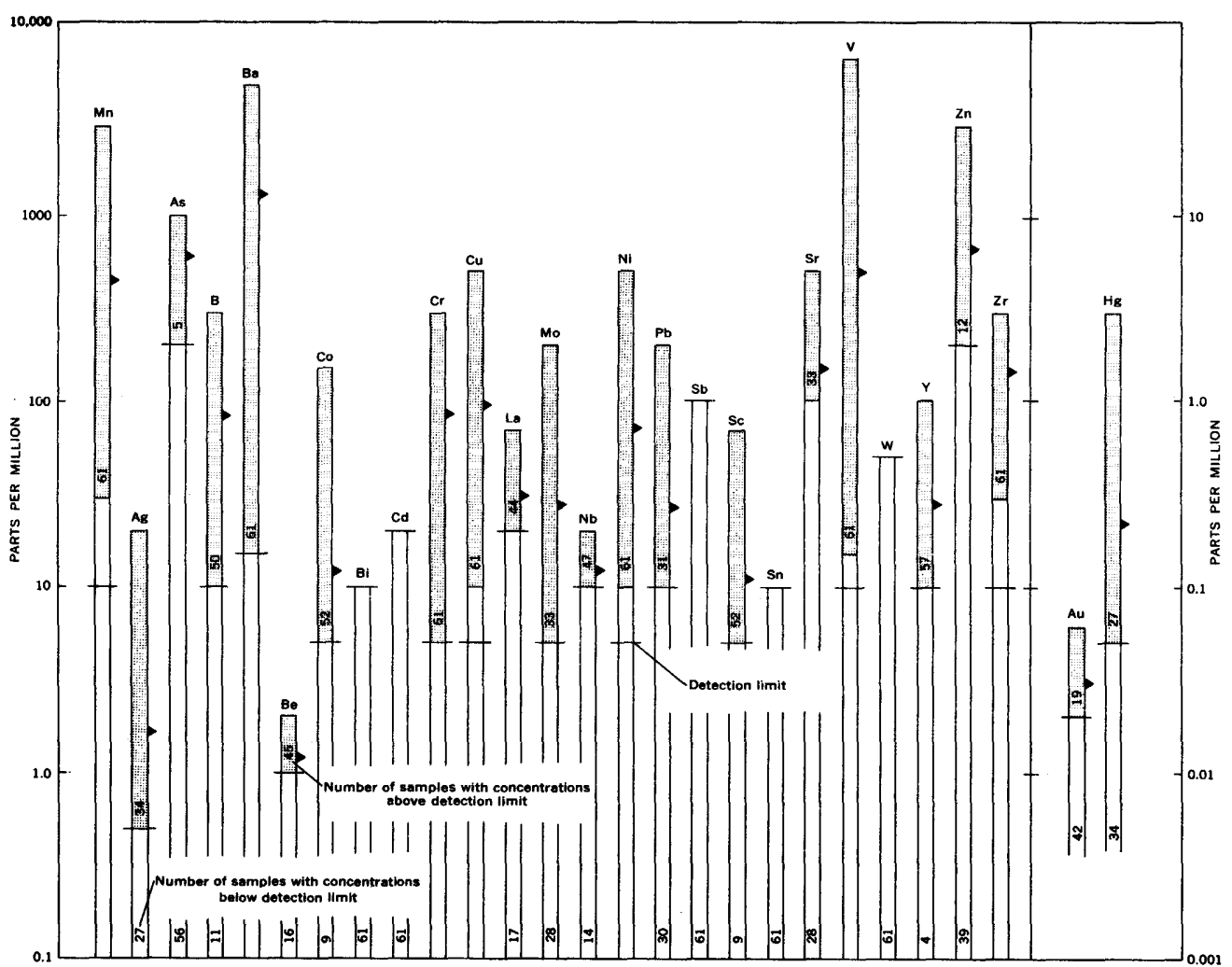


The arithmetic means of detectable gold in these intervals are 0.09 , 0.10 , and $0.04 \mathrm{ppm}$, respectively. Furthermore, gold in excess of 0.9 ppm occurs sporadically through core from both holes (table 6).

TABLE 6.-Drill core samples with anomalous concentrations of gold

\begin{tabular}{|c|c|c|}
\hline & & Description of sample \\
\hline & & DDH-1 \\
\hline & $\begin{array}{r}2.5 \\
1.0 \\
.9\end{array}$ & \multirow{3}{*}{$\begin{array}{l}\text { Bleached breccia. } \\
\text { Breccia with 8-inch zone of clay gouge. } \\
\text { Slightly bleached and brecciated chert and argillite. } \\
\text { Argillite, shaly, with pyrite along bedding. } \\
\text { 3-inch arsenopyrite-pyrite vein with trace of chalcopyrite and } \\
\text { sphalerite. } \\
\text { Clay gouge in brecciated greenstone. } \\
\text { Broad zone of higher gold background values; detectable gold in } 187 \\
\text { of } 221 \text { samples. Range: } 0.02 \text { to } 2.50 \text { ppm. Arithmetic mean: } 0.09 \text { ppm. } \\
\text { DDH-2 }\end{array}$} \\
\hline & & \\
\hline & & \\
\hline$, 420-1,42$ & & \multirow{5}{*}{$\begin{array}{l}\text { Pyrrhotite clusters, fine-grained crystals in clusters. } \\
\text { Arsenopyrite replacement vein }(20 \text {-ft composite vample across vein, } \\
\text { Au }=0.2) \text {. } \\
\text { 5-inch sphalerite-arsenopyrite-chalcopyrite-pyrite vein. } \\
7 \text {-inch quartz vein with } 2.5 \text { percent arsenopyrite. } \\
\text { 1-foot intercept, 5-10 percent arsenopyrite and } 1-2 \text { percent chalcopy- } \\
\text { rite. } \\
\text { 10-foot composite sample across vein at } 2,350 \text {. } \\
\text { Chert and argillite, includes } 3 \text {-inch pyrrhotite vein. } \\
\text { 2-inch pyrrhotite vein with trace of sphalerite. } \\
\text { Arsenopyrite-tremolite-actinolite vein. } \\
\text { Composite sample across vein at } 2,571 \text {. } \\
15 \text { of } 18 \text { samples between these intercepts have detectable gold. Range: } \\
0.04 \text { to } 0.50 \text { ppm. Arithmetic mean: } 0.10 \text { prm. } \\
6 \text {-inch sphalerite-pyrrhotite-chalcopyrite vein with calcite-tremolite- } \\
\text { actinolite gangue; slight bleaching. } \\
\text { Granite felsite with disseminated pyrrhotite-arsenopyrite-chalcopyrite. } \\
27 \text { of } 30 \text { samples between these intercepts have detectable gold. Range: } \\
0.02 \text { to } 0.10 \text { ppm (excluding sample at } 4,333) \text {. Arithmetic mean: } \\
0.04 \text { ppm. }\end{array}$} \\
\hline & & \\
\hline & & \\
\hline & .10 & \\
\hline & & \\
\hline
\end{tabular}

Gold content is especially high in a few thin base-metal veins; however, most analyses from composite or channel samples across the veins indicate very little wallrock gold dissemination. There is one exception: a 10-foot composite sample across an arsenopyrite vein at a depth of 2,350 feet in the deeper hole (DDH-2) has 7.0 ppm gold, compared with $15 \mathrm{ppm}$ in the vein itself. Gold contents in sulfides from DDH-2 are higher than in similar sulfide samples from DDH-1.

\section{GEOCHEMISTRY OF DDH-1}

The distribution of several elements is strongly affected by the two intervals of bleached and altered rock containing pyrite and other sulfides in DDH-1 (pl. 2). The concentration of barium and manganese best reflects the extent of altered rock in the drill core; thus, the two elements may have been introduced during alteration. Zinc (sphalerite) is the metal most significantly introduced across the 15-foot-thick fault zone between 148 and 163 feet. From peak concentrations of greater than $10,000 \mathrm{ppm}$ at the fault zone itself, zinc concentrations decrease with depth and at about 800 feet fall below the detection limit. The distribution pattern for lead is very similar to that of zinc, but lead is much less abundant.

A few other metals, whose distribution does not significantly 
extend into the surrounding altered drill core, have been detected at fault zones. There are high concentrations of arsenic (arsenopyrite(?)) (pl. 2); the narrow arsenic distribution may result in part from the high detection limit for this element. A little molybdenum has also been introduced at the faults (pl. 2). Silver contents range from 7 to $50 \mathrm{ppm}$ across the sphalerite zone between 148 and 163 feet, compared with a silver background of about $1.0 \mathrm{ppm}$. Cadmium ranges from 150 to $500 \mathrm{ppm}$ across these veins. Cadmium background is $<20 \mathrm{ppm}$.

Copper, vanadium, and chromium have very similar distribution patterns in DDH-1 (pl. 2). These elements are two to three times more abundant in the lower $(750-1,100 \mathrm{ft})$ zone of alteration than they are below that zone. They have also been introduced into the upper altered zone (60-350 ft), but the relative amount of the introduction is more difficult to evaluate because of underlying black shales with high metal contents (pl. 2).

Across the several dikes penetrated by this hole, copper, vanadium, chromium, cobalt, and nickel contents are near or below the detection limits and thus much lower than in the siliceous rocks of the surrounding Scott Canyon Formation (pl. 2).

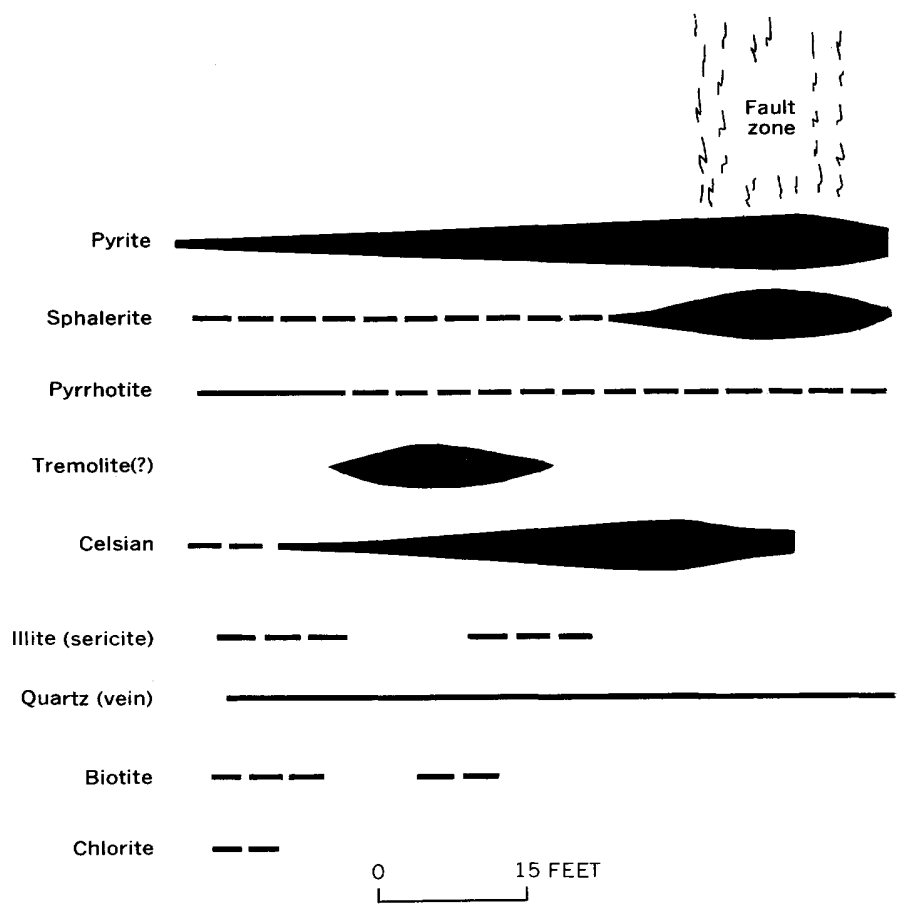

FIGURE 5.-Relative distribution of minerals adjacent to and in a fault breccia zone between 148 and 163 feet in DDH-1. 
In summary, the geochemistry and the sulfide-silicate assemblages detected in bleached, altered rock near faults in the upper part of this hole suggest a complex sequence of hypogene metal deposition superposed on rocks that had previously been pyritized (fig. 5). The widespread pyritization around the Copper Canyon stock is probably related to early postmagmatic fluids associated with potassic alteration assemblages in the core of the pyritized area (Nash and Theodore, 1971). Celsian and sphalerite at Iron Canyon were deposited probably near the end of the pyritic alteration range.

\section{GEOCHEMISTRY OF DDH_2}

Elemental concentrations (pl. 3) are remarkably uniform along the entire length of DDH-2. Lead contents are slightly higher than background in two broad zones: from the surface to about 1,700 feet and from 2,600 to 3,400 feet. Arsenopyrite may have been introduced together with galena in the lower zone, because arsenic contents there are above background level. Several other elements are also dispersed at values higher than background across certain intervals of drill core from this hole: copper contents are generally high in the upper 1,500 feet, and zinc is more abundant in the upper 400 feet than in the lower parts.

\section{GOLD AT THE SURFACE}

\section{DISTRIBUTION}

The Iron Canyon area has been thoroughly prospected since the 1860 's, and the mines and prospect pits have been periodically examined by geologists and engineers. This area is within a zone of gold-silver mineralization peripheral to a copper-gold-silver zone centered near the Copper Canyon stock (Roberts and Arnold, 1965, p. B34). Metal production at Iron Canyon has been principally from the Iron Canyon, Buzzard, Butte, and Post mines.

Of the two holes, DDH-2 has the highest anomalous gold concentrations (table 6). This hole is about 150 feet east of the main strand of the Butte fault zone (pl. 1). Surface samples collected along this zone also commonly have anomalously high gold concentrations (pl. 1). The concentrations of gold in composite grab samples collected from two underground workings along this fault zone, near DDH-2, are shown in figure 6 . The highest gold concentrations here are in brown to reddish-brown iron oxides along discrete fault surfaces. At Iron Canyon, concentrations of gold in iron oxide gossans, derived from sulfides, suggests leakage of goldbearing solutions from below. The distribution pattern for gold at Iron Canyon (pl. 1) reflects, at a much larger scale, the fact that 
gold metallization generally is structurally controlled throughout the district. Although gold contents are high in mines and prospect

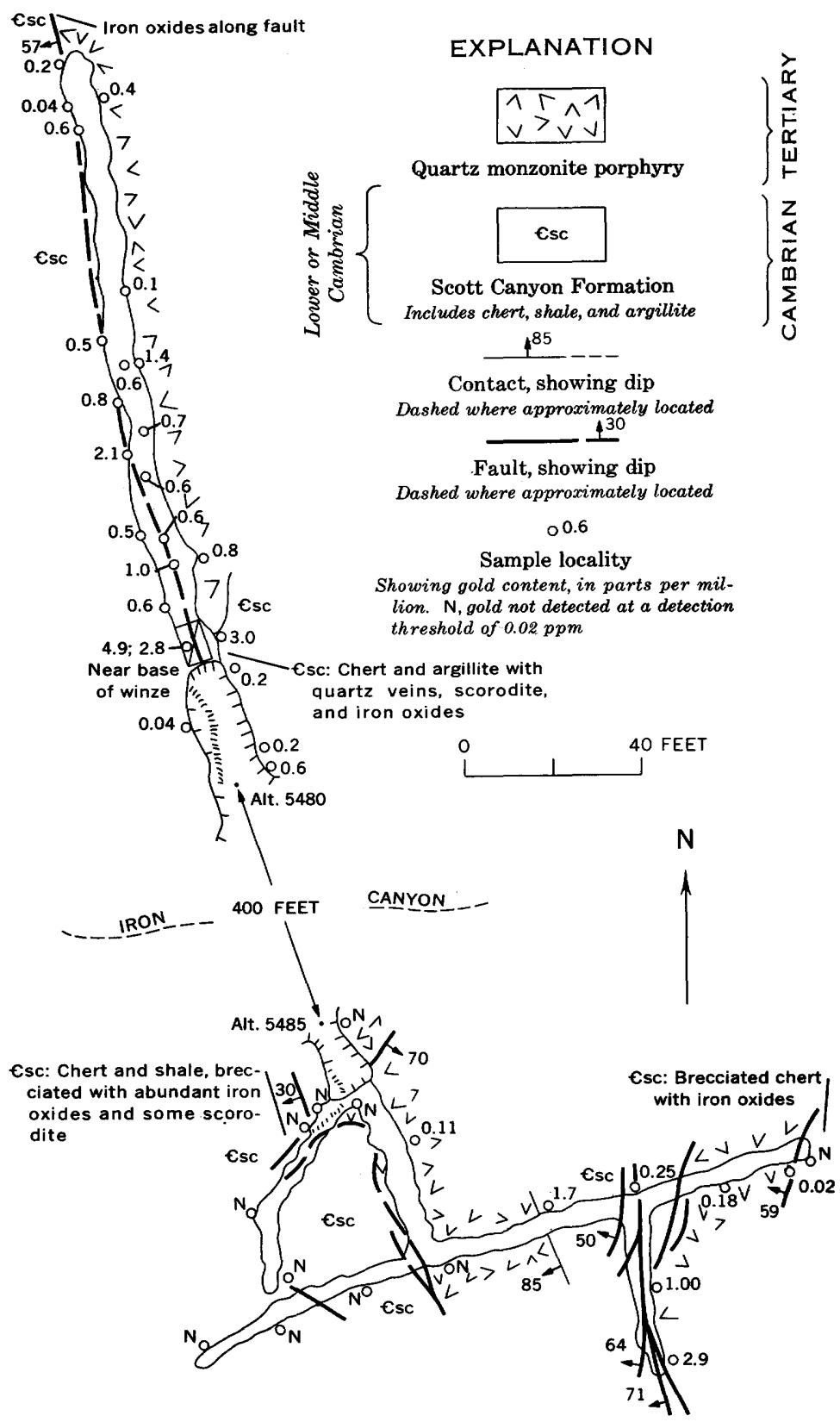

Figure 6.-Distribution of gold (in parts per million) in grab samples collected in underground workings along the Butte fault zone. 
pits along faults at Iron Canyon, there is no broad dispersal of gold in the host rock near many of the mines. For example, high gold contents clearly define the 15-foot-wide Buzzard vein (pl. 1), but bleached impervious chert near the vein has no detectable gold, nor do there appear to be structures that could have allowed lateral migration of the gold-bearing solutions. High gold concentrations cluster around several prospects about 0.7 miles east of the Buzzard mine; these concentrations are near and at shallow workings that follow fault contacts between the Scott Canyon and Harmony Formations (pl. 1). The specific locations of the samples with high gold concentrations show that the surface distribution of gold is controlled by faults even within this 1,000 -foot-square area.

\section{ASSOCIATION WITH OTHER ELEMENTS}

Varying amounts of gold were detected in 364 of 1,384 surface samples from the Iron Canyon area, and the reported concentrations of gold were compared statistically with the associated concentrations of $\mathrm{Mg}, \mathrm{Fe}, \mathrm{Ca}, \mathrm{Ti}, \mathrm{As}, \mathrm{Sb}, \mathrm{V}, \mathrm{Mo}, \mathrm{Sn}, \mathrm{Ni}, \mathrm{Cr}, \mathrm{Ba}, \mathrm{Sr}, \mathrm{B}, \mathrm{Pb}$, $\mathrm{Mn}, \mathrm{Bi}, \mathrm{Be}, \mathrm{Cd}, \mathrm{Cu}, \mathrm{Zr}, \mathrm{Ag}, \mathrm{Zn}, \mathrm{Co}$, and $\mathrm{Hg}$. The distribution of gold and many of the other elements is nonnormal (fig. 7). Furthermore, frequency distributions of many of the elements extend beyond the upper or lower detection limits, and the spectrographic concentrations reported are ranked data. These characteristics of the geochemical data from Iron Canyon would open to question any computations of strengths of associations inferred from standard product moment correlation techniques betweeri selected elements. Product moment correlation coefficients are based on assumptions of bivariate normal distributions (Dixon and Massey, 1951, p. 162164; Lovering and others, 1968, p. B113). Therefore, the strength of association between gold and the other elements from six subareas (fig. 8) that represent the Iron Canyon area were determined by Spearman's nonparametric rank-correlation tests, which make no assumptions about the population distribution (Siegel, 1956, p. 202-213). Then the data from these six subareas were studied by product moment correlation techniques to determine the effect of nonnormal distributions on the element association strength derived by this technique. Finally, because no large variations in correlation values between the two techniques were noted, the strength of association between the various elements analyzed and gold across the entire Iron Canyon area was approximated by product moment correlation techniques. It was not possible to determine the strength of association between gold and these elements in the entire Iron Canyon area by Spearman rank-correlation techniques because computations based on the total number of samples col- 
lected $(1,384)$ would have exceeded the core capacity of the IBM $360 / 65$ computer (R. Terrazis, oral commun., 1969).

Rank-correlation associations of elements within the pyrite alteration halo at Iron Canyon indicate strong positive association between gold and the following elements, at a 99 percent confidence limit: $\mathrm{Cu}, \mathrm{Fe}, \mathrm{Bi}, \mathrm{Ag}, \mathrm{Hg}$, and $\mathrm{As}$ (in order of decreasing statistical significance) (fig. 8). It should be noted that there is no strong

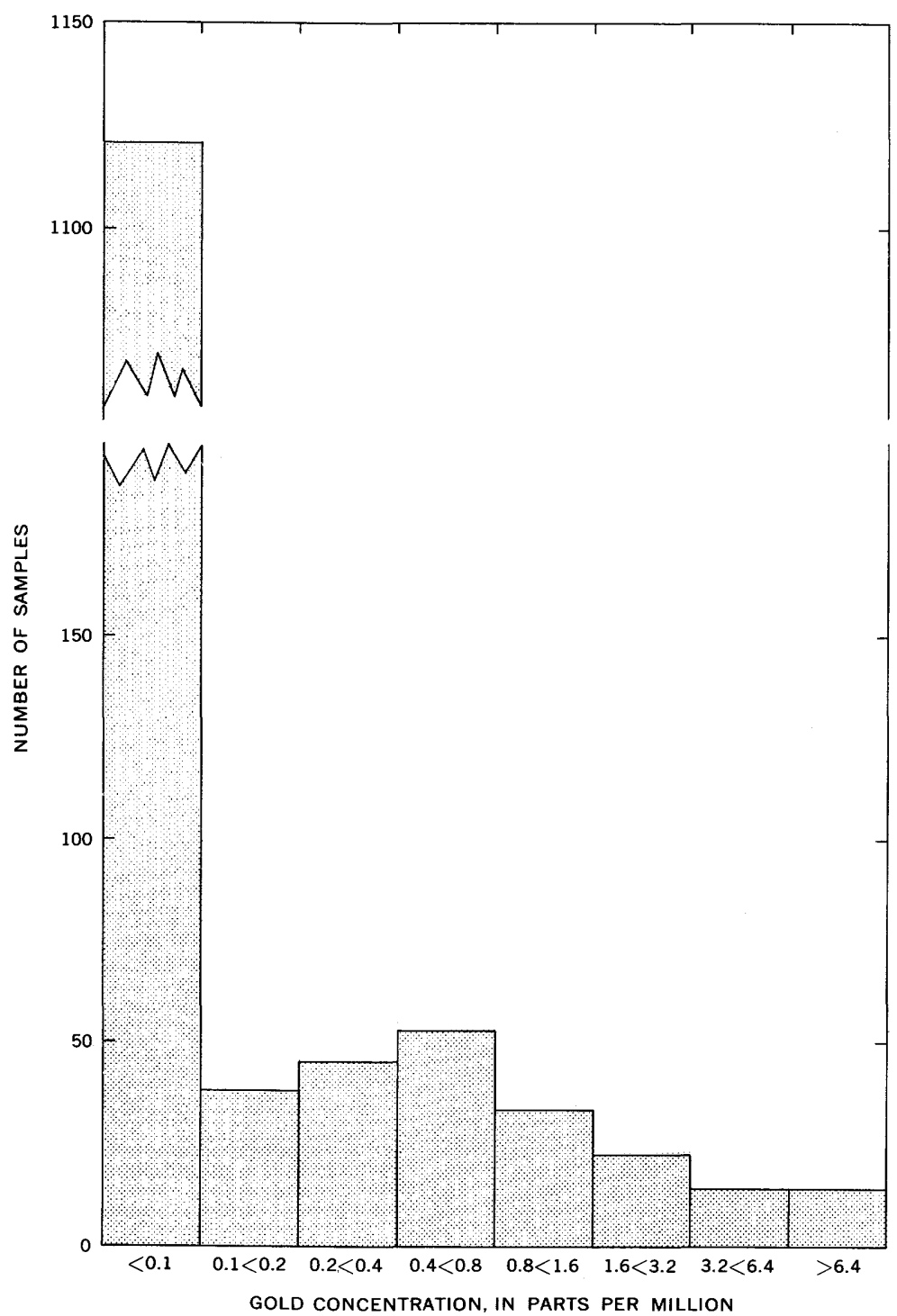

FIGURE 7.-Frequency distribution of gold in all surface samples collected in the Iron Canyon area. 
association between the element pairs gold-barium and gold-manganese in the zone of introduced pyrite. Since there was notable introduction of barium and manganese concomitant with the alteration at Iron Canyon, some gold here may have been introduced before, or even after the pyritic alteration itself. Native gold was introduced during the last stages of metallization in more intensely altered rock near the core of the pyrite zone at Copper Canyon (Nash and Theodore, 1971).

The number of elements strongly associated with gold generally decreases radially outward from the pyritic rocks, which contain many of the known deposits in the mining district. An exception to this general association is a narrow zone along the Butte fault system (subarea V, fig. 8), which is about 1,200 feet from the pyrite zone.

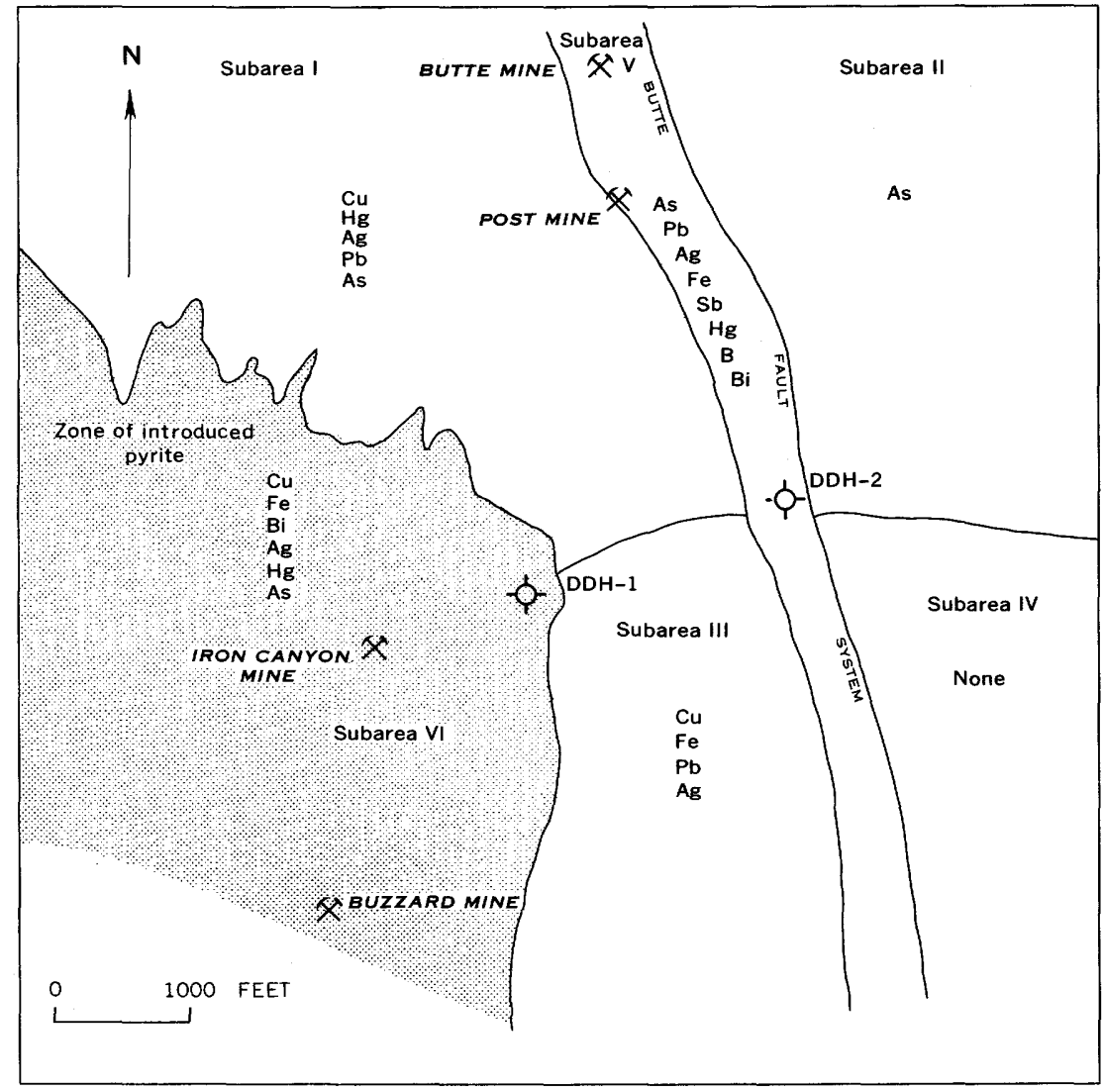

Figure 8.-Elements that have significant (at a 99-percent confidence limit) positive Spearman correlation coefficients with gold at Iron Canyon. Elements listed in order of decreasing significance. 
The strong association between the element pairs gold-copper and gold-silver detected in the pyrite zone persists into the immediately adjacent, relatively pyrite-free ground (subareas I and III, fig. 8). Gold and lead are also strongly associated in subareas I and III. However, the strong association of gold with mercury and arsenic in subarea I was not detected in subarea III. All elements (except copper) strongly associated with gold in the pyrite zone were also found to be strongly associated with gold along the Butte fault system (subarea $V$ ). The element pair with the strongest association along the fault is gold-arsenic; lead, antimony, and barium are also strongly associated with gold along the Butte fault system-associations not detected in the pyritic rocks. The strong gold-arsenic association along the fault suggests that here gold was deposited with arsenopyrite.

Strengths of association for gold in each of the subareas (fig. 8) based on product moment correlation coefficients are similar to the associations determined by Spearman techniques. However, the product moment correlation coefficients are generally somewhat less than the Spearman coefficients.

Several interesting relationships arose when the complete geochemical data set for the entire Iron Canyon area was studied by product moment correlation techniques. For the entire area, gold has positive product moment correlation coefficients with many elements: $\mathrm{Cd}, \mathrm{Fe}, \mathrm{Cu}, \mathrm{Bi}, \mathrm{Co}, \mathrm{Pb}, \mathrm{Ag}, \mathrm{Mo}, \mathrm{As}, \mathrm{Sr}, \mathrm{Hg}$, Sn, Sb, and $\mathrm{Cr}$ (in order of decreasing correlation coefficient). But the only strong positive associations are between the element pairs gold-copper, gold-iron, and gold-cadmium. Although Spearman and product moment techniques indicate strong gold-cadmium associations in three of the subareas, the associations are not statistically significant at 99 and 95 percent confidence limits (Spearman techniques) because of the small number of observation pairs. However, the cumulative effect of several strong but not statistically significant cadmiumgold associations in the small subareas that make up the entire Iron Canyon area eventually is reflected in the computations for the whole area associations.

The strong gold-cadmium association for the entire Iron Canyon area partly results from a high number of gold-cadmium pairs (33) in the total number of cadmium observations (48). However, the 48 samples with detectable cadmium (detection threshold $20 \mathrm{ppm}$ ) are a small fraction of the total number of samples collected $(1,384)$, and most of the 48 samples are from around the Iron Canyon mine (pl. 1), a lead-zinc deposit. Therefore, the gold-cadmium relationship is a local phenomenon, even within the small area of 
this study. The gold-copper and gold-iron associations are common throughout this part of the mining district.

Free gold was collected from the Iron Canyon placer about 150 feet west of DDH-2. The source must be close by because of Iron Canyon's restricted drainage basin. From about 15 grams of gold collected in the placer, 12 handpicked representative flakes $\mathbf{( 9 . 4 7}$ mg) were analyzed by custom semiquantitative six-step spectrographic techniques by A. L. Sutton, Jr. The placer gold contains: ppm

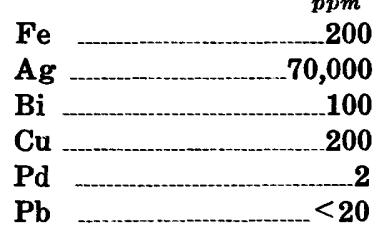

The following elements were looked for but not detected at different detection limits: $\mathrm{Mn}, \mathrm{Be}, \mathrm{Cd}, \mathrm{Co}, \mathrm{Cr}, \mathrm{La}, \mathrm{Mo}, \mathrm{Nb}, \mathrm{Ni}, \mathrm{Pt}, \mathrm{Sb}, \mathrm{Ss}, \mathrm{Sn}$, $\mathrm{V}, \mathrm{Y}, \mathrm{Zn}, \mathrm{Zr}, \mathrm{Ga}, \mathrm{In}, \mathrm{Yb}, \mathrm{Ir}, \mathrm{Rh}$ and $\mathrm{Ru}$.

The occurrence of copper and bismuth suggests that the Iron Canyon placer gold was derived from a lode source within the zone of introduced pyrite (fig. 8), because statistical tests of surface sample analyses indicate significant strong associations between both gold-copper and gold-bismuth only within the pyrite zone at Iron Canyon. Gold and bismuth are associated along the Butte fault (subarea V, fig. 8), but not as strongly as in the pyrite zone. Furthermore, gold and copper are not significantly associated along the Butte fault.

The isotopic composition of lead in the Iron Canyon placer gold concentrate was analyzed by Bruce R. Doe and Maryse H. Delevaux. Rutile, sphene, zircon, topaz, and galena were handpicked from a panned gold concentrate, the remaining gold was dissolved in aqua regia, and lead was separated from gold on a chloride anion exchange resin column (B. R. Doe, written commun., 1967). A considerable residue remained after the aqua regia dissolution, indicating that most of the gold nuggets had a core of some mineral not affected by the aqua regia. The isotopic composition of the lead (which might be from entrapped galena) is

$$
\frac{\mathrm{Pb}^{206} / \mathrm{Pb}^{204}}{19.39} \frac{\mathrm{Pb}^{207} / \mathrm{Pb}^{204}}{15.76} \frac{\mathrm{Pb}^{208} / \mathrm{Pb}^{204}}{39.23}
$$

This isotopic composition is very similar to that found in galena from various lead-silver prospects elsewhere in north-central $\mathrm{Ne}$ vada (B. R. Doe, written commun., 1967). The age of gold metallization at Iron Canyon is probably late Eocene or early Oligocene (Roberts and others, 1971). 
The gold associations at Iron Canyon do not differ much from the gold-base-metal associations elsewhere in north-central $\mathrm{Ne}$ vada. Gold at the Cortez gold deposit is associated with mercury, arsenic, antimony, and tungsten anomalies (Erickson and others, 1966; Wells and others, 1967). Around the Gold Acres and Tenabo mining camps, arsenic, cadmium, mercury, and zinc are concentrated where gold concentrations are highest (Wrucke and others, 1968, p. 5). At the Carlin gold deposit, there are mercury, arsenic, and antimony anomalies (Erickson and others, 1966). Elliott and Wells $(1968$, p. 6) reported that all rocks sampled in a geochemically anomalous area at Mill Canyon, in the Cortez quadrangle, display strong associations between gold and arsenic. However, the distribution of silver, lead, zinc, copper, arsenic, and antimony anomalies in the Mill Canyon area also reflects the distribution of gold (Elliott and Wells, 1968, figs. 4-11).

\section{DISTRIBUTION OF ARSENIC, TIN, BARIUM, AND COPPER AT THE SURFACE}

The surface distribution patterns at Iron Canyon for arsenic, tin, barium, and copper (pl. 1) are also strongly controlled by fault traces. The arsenic distribution pattern is very similar to that of gold: there are high arsenic concentrations along the Butte fault system, and many samples in the altered area also contain anomalously high concentrations. Near the southeast corner of the Iron Canyon area, east of the Butte fault system trace, arsenic background values are slightly higher than elsewhere. Structural controls most strikingly affect the distribution pattern of tin at Iron Canyon. Tin is concentrated along the Butte fault, along the Buzzard vein, and also along a minor thrust between Scott Canyon greenstones and underlying cherts and argillites in the west-central part of the area. High barium concentrations cluster in and near the altered area (pl. 1) reflecting the introduction of celsian here as described previously. The distribution pattern of copper is more diffuse than that of the other elements, yet highest concentrations of this element are commonly within the areas of altered rock at Iron Canyon.

\section{GEOPHYSICAL LOGS OF DRILL HOLE DDH-2}

\section{By Charles J. Zablocki}

Continuous natural gamma-ray intensity and electrical resistivity measurements were made in DDH-2 between depths of 1,814 and 3,965 feet (pl. 4). The logged interval was limited by the extent of the steel casing left in the hole and by the maximum length of the cable used in these studies. This 2,151-foot section is neverthe- 
less representative of the major rock types penetrated by the two holes; therefore, the results can probably be extrapolated to similar rock types in other sections of the holes.

Gamma-ray intensity was measured with a scintillation-type detector using an integration time constant of 4 seconds at a logging speed of 0.5 feet per second. The system records the total count; thus, radiation emitted at different energy levels by the common radioactive elements potassium-40, thorium, and uranium cannot be discriminated. The electrical resistivity measurements were made using a normal electrode configuration with 4- and 32-inch spacings. The shorter spacing provides greater resolution, but the influence of the conductive fluid in the borehole on the measurements is more severe than with the larger spacing. (For a description of these logging tools, see Pirson, 1963.) Plots of the relative gamma-ray intensity and the 32 -inch normal resistivity logs are shown on plate 4 , together with a corresponding generalized lithologic log.

\section{GAMMA-RAY INTENSITIES}

The relative amplitudes of gamma radiation in the zones of higher intensity throughout the logged section generally do not exceed two to three times the average background level. These higher intensities correlate with sections that contain carbonaceous shale (black and (or) graphitic(?)) or with some of the intrusive zones. Definitive examples for the carbonaceous shale sections are at depths of about $2,195,2,250,2,325-2,350$, and 3,060-3,070 feet and for the intrusive rocks at 2,007 feet (felsite porphyry). Notable exceptions-sections of carbonaceous shale and intrusive rocks in which gamma-ray intensities are not above background-occur below 3,430 feet and at 2,829-2,877 feet, respectively.

Gamma-ray spectral analysis by C. M. Bunker (written commun., 1969) of three shale samples from depths of $3,539,3,757$, and 3,815 feet in DDH-2 indicated about $5.5 \mathrm{ppm}$ average uranium content and about $7 \mathrm{ppm}$ thorium. A potassium analysis on one sample indicated 2.15 percent by weight, of which 0.01 percent would be the radioactive isotope potassium-40. These values would indicate that all three constituents contribute fairly equally to the total gammaray intensities measured. One sample from the quartz porphyry section at 3,200 feet had $16.8 \mathrm{ppm}$ uranium and $4.9 \mathrm{ppm}$ thorium. The higher uranium content in this sample, as compared with the shale samples, probably contributes the most to the total intensity recorded in this zone. The high intensity related to the felsite porphyry zone at 2,007 feet might be caused by a greater abundance of potassium feldspar. 


\section{ELECTRICAL RESISTIVITY}

The electrical resistivity of most rocks depends primarily on water-amount, salinity, and manner of distribution. Generally the waterfilled porosity of a rock most affects its resistivity. Water may reside in the intergranular pore spaces of clastic sedimentary rocks, within the crystals of igneous rocks, or in fractures in many different kinds of rock. The cation exchange properties of surfaceactive materials such as clay tend to increase conductivity because of the addition of exchangeable ions to the pore water (doublelayer conductivity).

The resistivities of rocks containing conductive minerals, such as massive sulfides and graphite, are controlled predominately by electronic or solid-state conduction processes, in which water is not involved. The quantity of these conductive minerals needed to render a rock electronically conductive depends on their mode of occurrence in the rock framework. In general, resistivity is appreciably lower if these minerals are physically continuous over large sections of the rocks.

Examples of each of these three effects can be found in the resistivity log (pl. 4).

The dynamic range in the resistivity values shown on the log of drill hole DDH-2 is extremely large: from less than $1 \mathrm{ohm}-m e t e r$ to over $4,000 \mathrm{ohm}$-meters. Resistivities correlate fairly consistently with the generalized rock-type description throughout the logged interval.

Resistivities exceeding $800 \mathrm{ohm}$-meters reflect zones in which rocks have very low intergranular or intercrystalline porosities (less than 0.2 percent) and virtually no fractures or conductive minerals. Typical zones are those described as: gray chert, quartzite, limy shale, brown shale, limestone, and quartz porphyry. Values in excess of $2,000 \mathrm{ohm}$-meters indicate rocks with almost zero effective porosity. Good examples are the quartz porphyry sections between 3,170 and 3,235 feet, the hornfelsic brown shale section between 3,300 and 3,430 feet, and the quartz veins below 3,900 feet. Brown hornfelsic shales (dense, hard, and recrystallized) have the highest resistivity recorded in this drill hole. It is interesting to note also that the upper part of the aforementioned quartz porphyry intrusive contains perhaps 5-10 percent quartz phenocrysts, whereas the middle and lower sections contain 15-20 percent. Phenocrysts apparently decrease the effective intercrystalline porosity of the rocks, thereby accounting for the much larger resistivities.

Granodiorite in the section below 2,820 feet is slightly altered 
and thus might contain enough clay minerals to render it less resistive than the quartz porphyry zone immediately below it. Similarly, the clay content of the chert-clay zone below 2,400 feet is probably sufficient to render this zone less resistive than the nonclayey chert zones below it.

Although most of the recovered core samples were extremely competent, some were fractured and, thus, less resistive. Examples are the breccia zones near 1,900 and 3,440 feet and the fractured limestone zone near 2,085 . The resistivity of the limestone section near 3,290 feet, however, is much higher than are the resistivities for most of the other reported limestone sections. Any small fractures that might have developed in this zone have probably been filled with calcite, as noted on the lithologic log.

An example of electronic conduction due to metallic mineral concentration is shown at about 1,970 feet, where a small zone of massive pyrrhotite must largely account for the virtually zero resistivity (much less than $1 \mathrm{ohm}$-meter).

Perhaps the most interesting finding was that carbonaceous material greatly decreases the resistivities of these rocks. Although some graphite may be present, much of the carbon probably is amorphous, and the nature of conduction in rocks containing amorphous carbon has not been adequately investigated.

The logs show clearly that those sections containing black and (or) graphitic(?) shale are electronically conductive (virtually zero resistivity). Even in some sections that, for simplicity in presentation, are generalized as "chert with black shale," the conductive zones are clearly identified with a correspondingly high gamma-ray intensity (as, for example, around 3,075 ft). A carbon analysis of the three shale samples analyzed for uranium and thorium indicated an average total organic carbon content of about 3 percent. If these extremely low carbon content samples are representative of the other black shale sections, then it is rather surprising that such a low carbon content would render the rock so conductive. However, microscopic examination of a thin section from a sample of chert with black shale from 4,402 feet (cataclastic chert fragments surrounded by black shale) revealed many thin long stringers of black carbonaceous material. These stringers clearly showed evidence of physical continuity in various sections of the sample. Furthermore, on core samples composed largely of chert with only minor amounts of black shale partings, electrical continuity could selectively be found using a simple, two-electrode, ohmmeter.

Apparently, small changes in the relative abundance of small amounts of carbon in a section do not affect the resistivity of that 
section significantly. This is especially true if the textural mode of the carbon is discontinuous. Compare, for example, the high resistivity (about $600 \mathrm{ohm}$-meters) section between 1,814 and 1,867 feet described as light-gray chert, with the relatively low resistivity (about $200 \mathrm{ohm}$-meters) section immediately below, which is chert with black shale, or with the still lower resistivity zone $(20 \mathrm{ohm}-$ meters) near 2,920 feet, described as dark-gray shale.

The results of these geophysical measurements do not provide any notable correlation with the reported geochemical data. However, the logs do provide a useful supplement to the core analysis and description in that they aid in placing descriptive boundaries in sections where many different rock types are interbedded. Also, knowledge of the measured properties of these rocks can help the exploration geophysicist assess the applicability of various surface exploration techniques (radioactivity and electrical) in similar geologic environments.

\section{SUMMARY}

At Iron Canyon, integrated studies of the primary surface distribution of gold, its trace element associations, and the isotopic composition of lead in gold collected from a small placer deposit have yielded abundant background information fundamental for exploration programs by the mining industry. The strong effect of structural controls on the distribution of gold at the surface has been documented ( $\mathrm{pl} .1$ ), and the response of elements strongly associated with gold to changing geologic environment has also been shown (fig. 8). The trace element content of the placer gold suggests that the gold here was derived from lode deposits within a broad zone of introduced pyrite.

The shallower hole (DDH-1) provides an excellent geochemical contrast at depth between the altered (pyritic) and the unaltered rocks of the Scott Canyon Formation. The most interesting find from the resistivity logs of DDH-2 is that a total organic carbon content of only about 3 percent apparently is enough to reduce the electrical resistivity of a rock to less than $1 \mathrm{ohm}$-meter. The physical continuity of black carbonaceous material (graphite?) along bedding planes in the Scott Canyon Formation may explain this low resistivity.

\section{REFERENCES CITED}

Blanchard, Roland, 1968, Interpretation of leached outcrops: Nevada Bur. Mines Bull. 66, 196 p.

Dixon, W. J., and Massey, F. J., 1951, Introduction to statistical analysis: New York, McGraw-Hill Book Co., Inc., 370 p. 
Elliott, J. E., and Wells, J. D., 1968, Anomalous concentrations of gold, silver, and other metals in the Mill Canyon area, Cortez quadrangle, Eureka and Lander Counties, Nevada: U.S. Geol. Survey Circ. 606, 20 p.

Erickson, R. L., Van Sickle, G. H., Nakagawa, H. M., McCarthy, J. H., Jr., and Leong, K. W., 1966, Gold geochemical anomaly in the Cortez district, Nevada: U.S. Geol. Survey Circ. 534, 9 p.

Grimes, D. J., and Marranzino, A. P., 1968, Direct-current arc and alternationcurrent spark emission spectrographic field methods for the semiquantitative analysis of geologic materials: U.S. Geol. Survey Circ. 591, 6 p.

Hardie, B. S., 1966, Carlin gold mine, Lynn district, Nevada: Nevada Bur. Mines Rept. 13, pt. A, p. 73-82.

Huffman, Claude, Jr., Mensik, J. D., and Riley, L. B., 1967, Determination of gold in geologic materials by solvent extraction and atomic-absorption spectrometry: U.S. Geol. Survey Circ. 544, 6 p.

Lovering, T. G., Lakin, H. W., and Hubert, A. E., 1968, Concentration and minor element association of gold in ore-related jasperoid samples, in Geological Survey research, 1968: U.S. Geol. Survey Prof. Paper 600-B, p. B112-B114.

Nash, J. T., and Theodore, T. G., 1971, Ore fluids in a porphyry copper deposit at Copper Canyon, Nevada: Econ. Geology, v. 66, no. 3, p. 385-399.

Pirson, S. J., 1963, Handbook of well log analysis: New Jersey, Prentice-Hall, Inc., $326 \mathrm{p}$.

Roberts, R. J., 1964, Stratigraphy and structure of the Antler Peak quadrangle, Humboldt and Lander Counties, Nevada: U.S. Geol. Survey Prof. Paper 459-A, $93 \mathrm{p}$.

1966, Metallogenic provinces and mineral belts in Nevada: Nevada Bur. Mines Rept. 13, pt. A, p. 47-72.

Roberts, R. J., and Arnold, D. C., 1965, Ore deposits of the Antler Peak quadrangle, Humboldt and Lander Counties, Nevada: U.S. Geol. Survey Prof. Paper 459-B, 94 p.

Roberts, R. J., Hotz, P. E., Gilluly, James, and Ferguson, H. G., 1958, Paleozoic rocks in north-central Nevada: Am. Assoc. Petroleum Geologists Bull., v. 42, no. 12, p. 2813-2857.

Roberts, R. J., Radtke, A. S., and Coats, R. R., 1971, Gold-bearing deposits in north-central Nevada and southwestern Idaho, with a section on Periods of plutonism in north-central Nevada by Miles L. Silberman and Edwin H. McKee: Econ. Geology, v. 66, no. 1, p. 14-33.

Sayers, R. W., Tippett, M. C., and Fields, E. D., 1968, Duval's new copper mines show complex geologic history: Mining Eng., v. 20, p. 55-62.

Siegel, Sidney, 1956, Nonparametric statistics-for the behavioral sciences: New York, McGraw-Hill Book Co., Inc. 312 p.

Theodore, T. G., and Blake, D. W., 1969, Geochemistry and geometry of the pyritic halo around the Copper Canyon stock at Iron Canyon, Lander County, Nevada [abs.]: Geol. Soc. America, Cordilleran Sec.-Paleont. Soc., Pacific Coast Sec., 65th Ann. Mtg., Eugene, Oreg., 1969, Program, pt. 3, p. 69.

Vaughn, W. W., and McCarthy, J. H., Jr., 1964, An instrumental technique for the determination of submicrogram concentrations of mercury in soils, rocks, and gas, in Geological Survey research, 1964: U.S. Geol. Survey Prof. Paper 501-D, p. D123-D127. 
Ward, F. N., Lakin, H. W., Canney, F. C., and others, 1963, Analytical methods used in geochemical exploration by the U.S. Geological Survey: U.S. Geol. Survey Bull. 1152, 100 p.

Wells, J. D., Erickson, Ralph, and Stoiser, L. R., 1967, Geology and mineralogy of the Cortez gold deposit, Nevada [abs.]: Mining Eng., v. 19, no. 12, p. 40.

Wrucke, C. T., Armbrustmacher, T. J., and Hessin, T. D., 1968, Distribution of gold, silver, and other metals near Gold Acres and Tenabo, Lander County, Nevada: U.S. Geol. Survey Circ. 589, 19 p. 